\title{
Simulation and Power Flow Control Using Switching's Method of Isolated Wind-Solar Hybrid Power Generation System with Battery Storage
}

\author{
E. Oguz, H. Çimen and Y. Oğuz
}

\begin{abstract}
In this paper, a battery-supported hybrid windsolar energy generation system with switching power flow control is presented to supply stable electrical power to two laboratories at the Electric \& Electronic Engineering Department. For this purpose, 600W 3-phase permanent magnet synchronous generator (PMSG) based on the wind power generation system (WPGS) and the solar power generation system (SPGS) consisting of 190W 3 pieces mono crystal solar panel were combined to build a $1170 \mathrm{~W}$ hybrid wind-solar power generation system (HWSPGS). The solar and wind power generation systems were used as the main energy sources while 100 Ah $12 \mathrm{~V} 6$ pieces gel jeep cycle accumulator groups were used as the energy storage device to ensure continuity of energy. Also dynamic modeling and switching power flow control of the battery supported the HWSPGS were performed using Matlab/Simulink in this study. Determining the switching positions of the charge control unit according to loading and battery charge situations of the HWSPGS, power flow control between the generation unit and consumer was made in planned manner. When the curves of electrical magnitudes obtained from simulation results were examined, it was determined that no big difference existed in electrical and mechanical magnitudes in parallel to dynamic behavior of the installed hybrid power generation system.
\end{abstract}

Index Terms-Wind power generation, solar power generation, hybrid power generation, battery storage, switching power flow control.

\section{INTRODUCTION}

$\mathrm{N}$ OWADAYS, electrical energy from day to day is known more as needed. Additionally, the amount of energy needed for generation and consumption and whether it is economic, productive and environmental friendly are the elements that increase the countries level development [1].

E. OGUZ, Çanakkale Onsekiz Mart University, Biga Vocational School, Department of Electrical and Energy, Çanakkale, Turkey. (e-mail: emrahoguz@comu.edu.tr)

H. ÇIMEN, Afyon Kocatepe University, Technology Faculty, Departman of Electrical \& Electronic Engineering, Afyonkarahisar, Turkey. (e-mail: hcimen@aku.edu.tr)

Y. OĞUZ, Afyon Kocatepe University, Technology Faculty, Departman of Electrical \& Electronic Engineering, Afyonkarahisar, Turkey. (e-mail: yukseloguz@aku.edu.tr)

Manuscript received February 9, 2017; accepted June 14, 2017. DOI: $10.17694 /$ bajece. 334348
The energy need of the world has been met mostly by fossil base fuels. For this reason, countries increasingly depend on such fuels. However, as the negative effects of fossil base fuels on environment have reached the peak levels, reserves are almost consumed, and foreign-source dependency of countries increases, researches on new energy sources have been inevitable. In this process, the most important researches have been on renewable energy sources that do not have negative effects on environment and renew themselves permanently [2].

In general, the renewable energy sources comprise mainly wind and solar energies, and also the non-fossil base energy sources such as hydroelectric, geothermal, biomass (wood, solid wastes, ethanol, etc).

The biggest share in renewable energy sources and electric energy generation of Turkey belongs to hydroelectric and wind energy. Though the share of wind and solar energies in electric generation is very small when compared to other world countries, it is expected that these shares will increase in the future. However, other countries have made contribution to electric energy generation using the wind turbine and solar cell together or separately since 1970s. In general, hybrid power generation systems installed using the renewable energy sources are used to meet the electric energy demand of residential areas in far distance from electric distribution network. There are some hindrances for electric energy generation existing separately from wind turbine or solar cell. The most important hindrances are that the generated electric energy is interrupted, and the first installation costs are high and the sufficient technological knowledge lacks [3-6].

While the electric energy can only be generated from the sun in daytime, the load remains without energy in the rest of the day. The wind energy does not have definite limits like solar energy, while the electric energy can be generated in some hours of day. The load may remain without energy in the rest of the day. As for the power cut during the day, the consumption surplus of energy generated in time zones when the energy generation can be made is stored in the battery and in time zones when the generation is insufficient; the load is fed from the battery to meet the energy need.

Electric energy that will be obtainable from the wind and solar energy differs depending on seasons. In winter months, electric energy generation from the sun may not be possible 
for day's time. Similarly, electric energy generation from wind in spring and summer months remains very low [4-8].

Solving the seasonal electric energy generation interruption problem by increasing battery capacity will increase the cost but may not be possible in many areas. Such interruptions may be removed to a great extent with the installation of hybrid power generation system by using the wind turbine and solar panel together depending on characteristics of the region [5].

The hybrid power generation systems are installed through parallel connection of two or more conventional and renewable energy generation systems to each other. The hybrid power generation systems are one of the best solution methods to meet the electric energy need of mini or micro networks far distance from energy generation and distribution centers and of small settlement units. Most commonly, the wind-solar hybrid power generation system is used [9-12].

For electric generation systems in various structures, recently, hybrid energy generation systems are realized by combining mainly the wind and the solar energy and fuel cells and soon. However, as more staff will be used for hybrid energy generation systems installed with more than one renewable energy source, the cost and installation area need will increase and structure and inspection of the system will become complicated [13].

In this paper, teaching the topic will start with the description of a battery-supported hybrid wind-solar energy generation system with some general background about how the system works with solar energy, wind energy, load and energy storage. This portion is theoretical and can be explained by the instructor in the class. After that, three steps of planning and building the hybrid system involving renewable energy and load forecasting, renewable energy farm scale optimization, power flow control will be studied by using SimPowerSystems toolboxes in MATLAB. This portion would need the use of a computer lab or it can be in the form of assignments to students depending on their knowledge about power systems.

By considering the stated reasons above, a battery supported with $1170 \mathrm{~W}$ wind-solar hybrid power generation system was installed to meet the electric energy required for small power receivers in two electric laboratories in the department of Electrical-Electronics Engineering at Afyon Kocatepe University. A hybrid power generation system related to dynamic behaviors of system components was modelled and simulated thanks to SimPowerSystems in the Matlab/Simulink program. The data obtained from the simulation block diagram of the system almost expressed the real-time electric and mechanical output magnitudes of the installed hybrid power generation system. By comparing the data from the real system to data obtained from the simulation study, the accuracy analysis and power flow control of the simulation study related to hybrid power generation system was realized in the planned manner.

\section{BATTERY-SUPPORTED WIND-SOLAR HYBRID POWER GENERATION SYSTEM AND MODELING}

General view of the installed battery supported wind-solar hybrid power generation system is given in Fig. 1. The installed hybrid power generation system consists of a $600 \mathrm{~W}$ wind turbine, 190W 3 pieces' solar panels, battery group, and 1200W hybrid charge control unit that enables the operation of these units in harmony and $3 \mathrm{~kW}$ full sinus wave inverter for consumers fed with alternative current.

Furthermore, the data related to the energy generated by the hybrid power generation system can be followed via the charge control unit in 10 second intervals and by means of the winpowernet interface program; it can be followed via computer and be recorded in a Microsoft Excel file

The dynamic modeling of each unit of the installed hybrid system in conformity to its real-time behaviors was realized using the SimPowerSystems in the Matlab/Simulink program. Then, each modeled unit was combined in the DC bus bar, and simulation model of the hybrid power generation system shown in Fig. 2 was established.

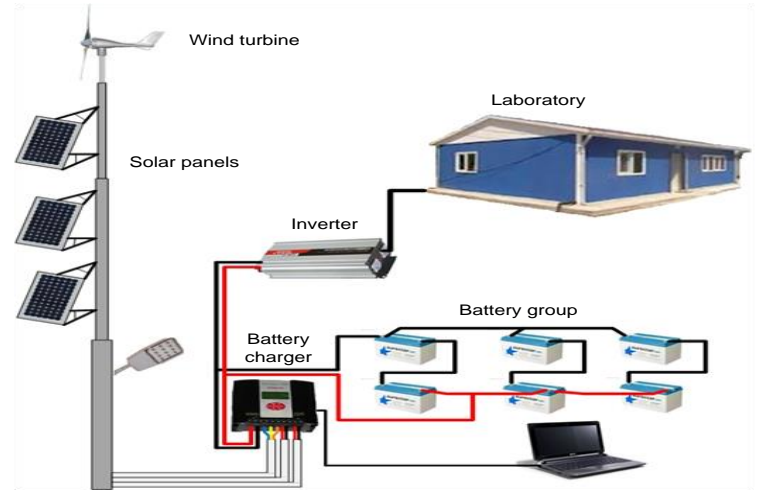

Fig. 1 General view of the installed battery powered wind-solar hybrid power generation system

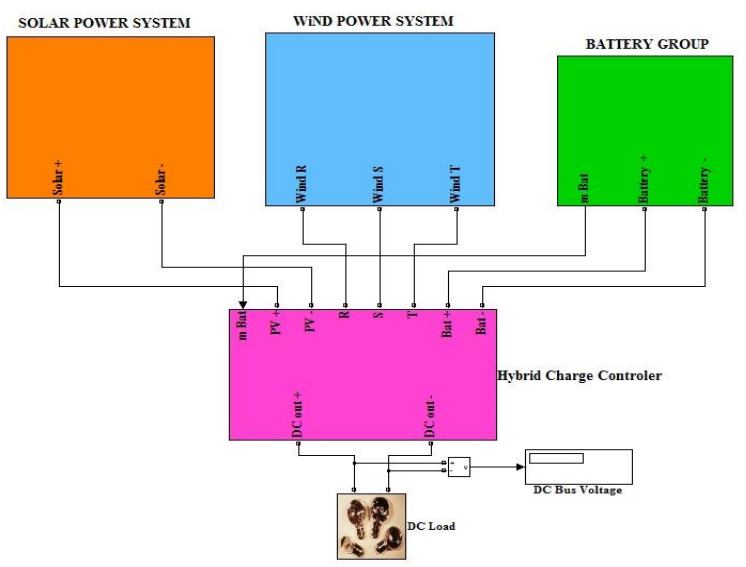

Fig. 2 Block diagram of the battery powered wind-solar power generation system 
Our first generation unit is the PMSG wind generation system. Some factors are important to determine the installation place of a wind turbine. Some of them are continuous and high wind speed and absence of elevations around the turbine that may obstruct the air flow. The simple operation of a wind turbine is as follows; when air flow hits to turbine wings, it causes the turbine wings to turn and as a result of this, the shaft where the turbine wings are connected turns. In small power wind turbines, this shaft is generally connected to generator directly but in huge power wind turbines, it is generally connected to generator by means of a gear box [11-15].

Generators convert mechanic energy to electric energy. While permanent magnet generators are used mostly in lower power wind turbines, in high power turbines, synchronous and asynchronous generators are used [16-18].

The wind turbine in the installed system has three wings and a two meter wing diameter. The turbine was directly coupled to the permanent magnet synchronous generator without using of gear box. The permanent magnet synchronous generator has 3 -phase $36 \mathrm{~V}$ output voltage and $600 \mathrm{~W}$ power. The wind power generation system starts to make a generation in speed of $2.5 \mathrm{~m} / \mathrm{s}$ and its maximum power generation value is $12 \mathrm{~m} / \mathrm{s}$. At $60 \mathrm{~m} / \mathrm{s}$ speeds, rotor is stopped mechanically.

Additionally, it may be stopped magnetically by making manual control on the charge control unit. According to the specifications given above, a wind power generation system model was established using the SimPowerSystems in the Matlab/Simulink program.
TABLE. 1 WIND TURBINE AND PMSG PARAMETERS

\begin{tabular}{|c|c|}
\hline \multicolumn{2}{|c|}{ Performance parameters } \\
\hline Measured power (W) & $\begin{array}{c}12 \mathrm{~V} 400 \mathrm{~W}-24 \mathrm{~V} 600 \mathrm{~W} \\
3 \text { phase AC }\end{array}$ \\
\hline Wind speed measured & 12 \\
\hline Start-up wind speed & 2.5 \\
\hline Maximum wind speed & Max.25 \\
\hline Wind speed to Disarm & 60 \\
\hline \multicolumn{2}{|c|}{ Motion parameters } \\
\hline Gear box & Unavailable \\
\hline Generator & Direct permenant magnet \\
\hline Rotor blades & $\begin{array}{l}3-\text { carbon fiber } \\
\text { reinforced plastic }\end{array}$ \\
\hline Diameter of the rotor blade (m) & 2 \\
\hline Rotor speed control & mechanical method \\
\hline Speed & 750 \\
\hline \multicolumn{2}{|c|}{ PMSG Electrical parameters } \\
\hline Stator phase resistance Rs $(\Omega)$ & 0.12 \\
\hline Inductances $[\mathrm{Ld}(\mathrm{H}) \mathrm{Lq}(\mathrm{H})]$ & $8.5 \mathrm{e}-3$ \\
\hline $\begin{array}{l}\text { Flux linkage established by magnets } \\
\text { (V.s) }\end{array}$ & 0.055133 \\
\hline Voltage constant (Vpeak L-L/krpm) & 36 \\
\hline Torque constant (N.m/A-peak) & 0.3308 \\
\hline $\begin{array}{l}\text { Inertia, friction factor, pole pairs } \\
{\left[\mathrm{J}\left(\mathrm{kg} \cdot \mathrm{m}^{\wedge} 2\right) \mathrm{F}(\mathrm{N} \cdot \mathrm{m} . \mathrm{s}) \mathrm{p}()\right]}\end{array}$ & {$[0.002,0.02,4]$} \\
\hline $\begin{array}{l}\text { Initial conditions [wm(rad/s) thetam } \\
(\mathrm{deg}) \mathrm{ia}, \mathrm{ib}(\mathrm{A})]\end{array}$ & {$[60,0,0,0]$} \\
\hline
\end{tabular}

The simulation block diagram of the wind power generation system with constant speed PM synchronous generator established is shown in Fig. 3. The parameters and values that belong to the wind turbine and PMSG are given in Table 1.

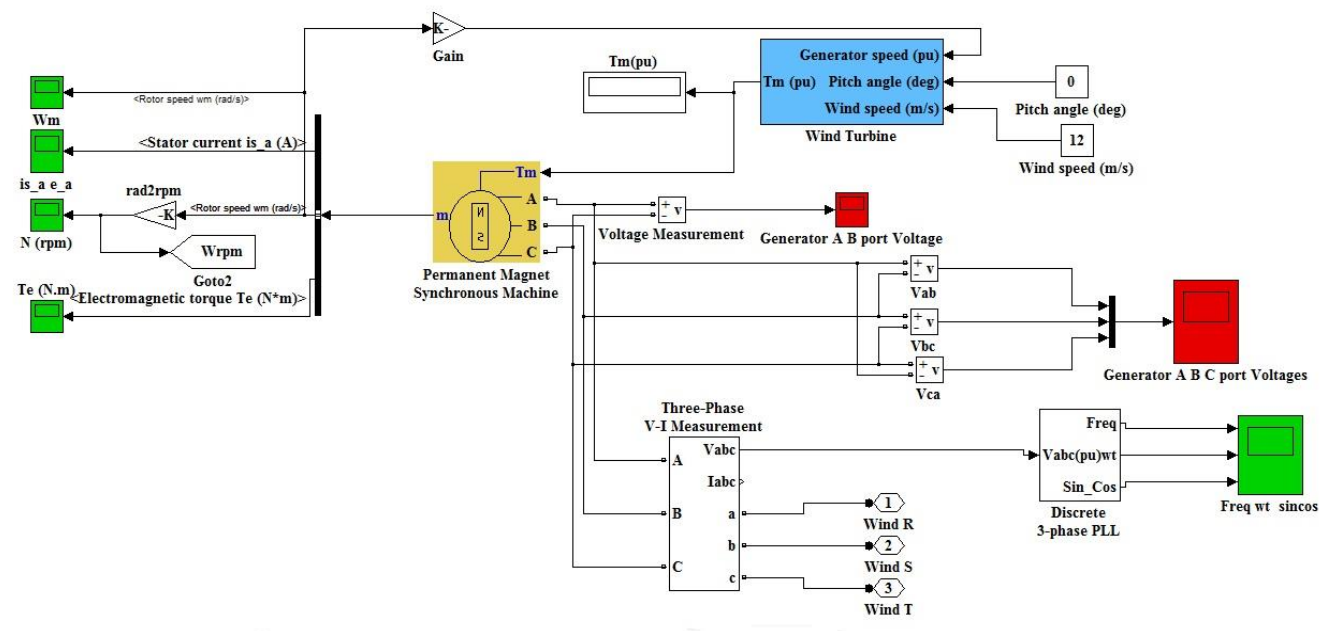

Fig. 3 Simulation Block Diagram of constant speed PMSG wind power generation system 
Our second generation unit is the solar power generation system established with parallel connection of solar panels. Solar panels convert the sun light to direct current electric energy. Sufficient light level is quite important in electric generation. Operational expenses of these generation systems are very low and its reliability is very high. In today's technology, solar panels in various sizes from a few watts to $300 \mathrm{~W}$ are manufactured. The biggest disadvantage of solar cells is their high cost. Usage period of solar panels varies between 10-25 years depending on their manufacturing technologies [19-22].

The solar power generation system in the installed hybrid system is in power of $570 \mathrm{~W}$ and established with parallel connection of 3 pieces of mono crystal solar panels in power of $190 \mathrm{~W}$. The photovoltaic panels used have the same features and consist of 72 cells, and their efficiency is $18 \%$. The electrical equivalent circuit of the photovoltaic cell is given in Fig. 4. This equivalent circuit is expressed with a mathematical formula in equation (1).The simulation block diagram of the solar panel was established in accordance with this formula. Then, a simulation block diagram of the solar power generation system was established with the parallel connection of 3 panels as shown in Fig. 5.

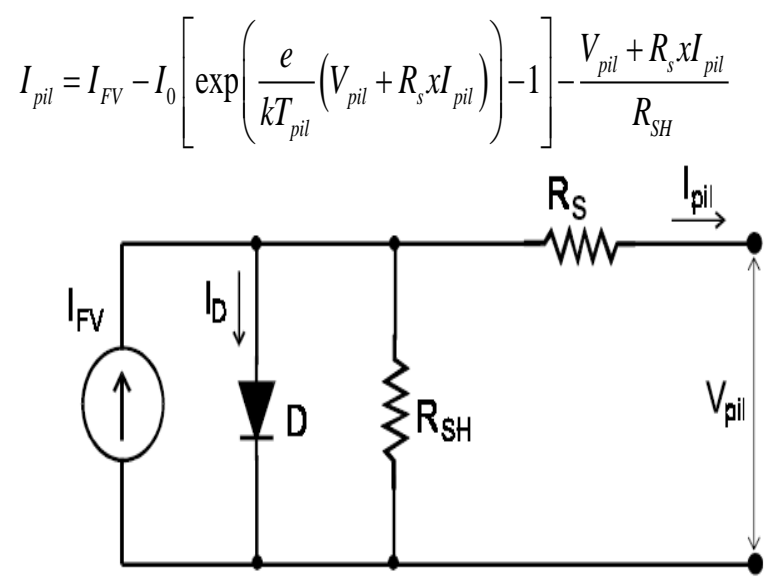

Fig. 4 Electrical equivalent circuit of a photovoltaic cell [8]

The electrical parameters and values of the solar panels used in this study are given in Table 2.

TABLE II. PARAMETERS OF PHOTOVOLTAIC PARAMETERS

\begin{tabular}{|l|l|l|}
\hline Parameters & Variables & Value \\
\hline Nominal Power (W) & $\mathrm{P}_{\max }$ & $190 \mathrm{~W}$ \\
\hline Maximum Power Voltage (V) & $\mathrm{V}_{\max }$ & $37.08 \mathrm{~V}$ \\
\hline Maximum Power Current(A) & $\mathrm{I}_{\max }$ & $5.12 \mathrm{~A}$ \\
\hline Open-Circuit Voltage (V) & $\mathrm{V}_{\mathrm{oc}}$ & $44.48 \mathrm{~V}$ \\
\hline Short-Circuit Current(A) & $\mathrm{I}_{\mathrm{sc}}$ & $5.54 \mathrm{~A}$ \\
\hline
\end{tabular}

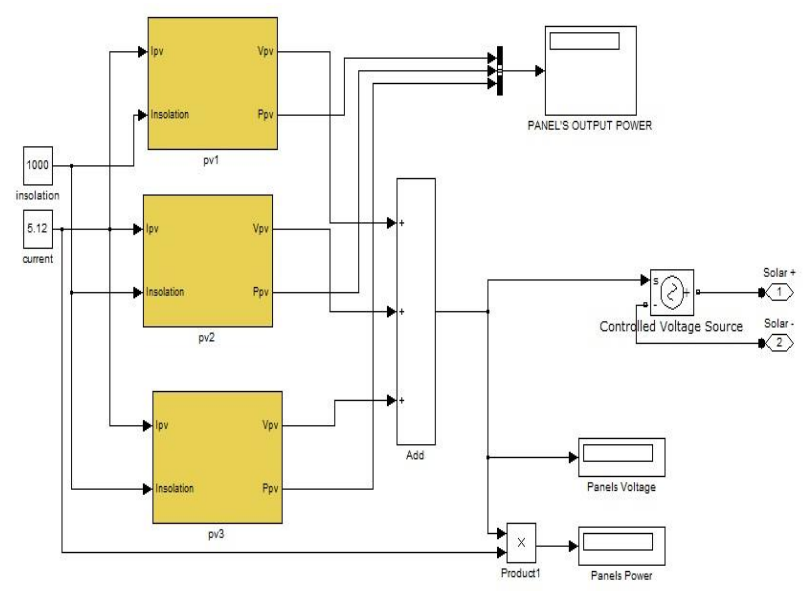

Fig. 5 Simulation Block Diagram of the Solar Power Generation System

The third unit is the battery group consisting of 6 pieces of $100 \mathrm{Ah}-12 \mathrm{~V}$ gel deep cycle accumulators that are used to store the consumer's surplus electric energy or to ensure continuousness of energy through renewable energy system in times when no generation is made. Batteries are electrochemical elements that store electric energy in chemical form. The battery types used together with renewable energy sources are lead- acid, nickel-cadmium, nickel-iron, iron-air batteries, and soon. Life of batteries varies between 1-10 years depending on operating conditions. Though the first investment costs of such batteries are low, their maintenance and renewal costs are very high. Today, gel accumulators are used in higher rates. Though their first investment costs are high, they do not have any maintenance costs. The battery capacities are expressed in $\mathrm{kWh}$ that is the multiple of $\mathrm{Ah}$ and nominal voltages [23-25].

Six pieces of $100 \mathrm{Ah}-12 \mathrm{~V}$ gel accumulators in the installed hybrid power generation system were connected in series in two groups and so three groups in $24 \mathrm{~V} 100 \mathrm{Ah}$ were established. Then, these groups by being connected as parallel among them power capacities in value of $24 \mathrm{~V} 300 \mathrm{Ah}$ were obtained.

Our last unit is the charge unit, the brain of the hybrid power generation system that is used to connect the power generation units to each other as parallel on a bus bar, charge the accumulator group, and feed the receiver in a controlled manner. Electric energy coming from the PMGS wind power generation system and solar panels to the control unit may come from both when the weather is windy and sunny or only from one of them when the wind or sun is effective.

It is completely depends on whether the weather is sunny and windy at the moment of operation. Additionally, in PM generator of the wind turbine, a 3-phase alternative voltage is generated and in the solar panel, a direct voltage is generated. For parallel connection of these two systems, their energy forms and magnitudes must be the same. This is provided by the hybrid charge control unit as shown in Fig. 6. The charge controller converts 3-phase AC voltage coming from the PM generator to the desired DC form and magnitude with AC/DC converter, and the DC voltage coming from solar panels to the 
desired magnitude with DC/DC converter; and, it transfers them to outside as battery charge voltage by combining the converter outputs.

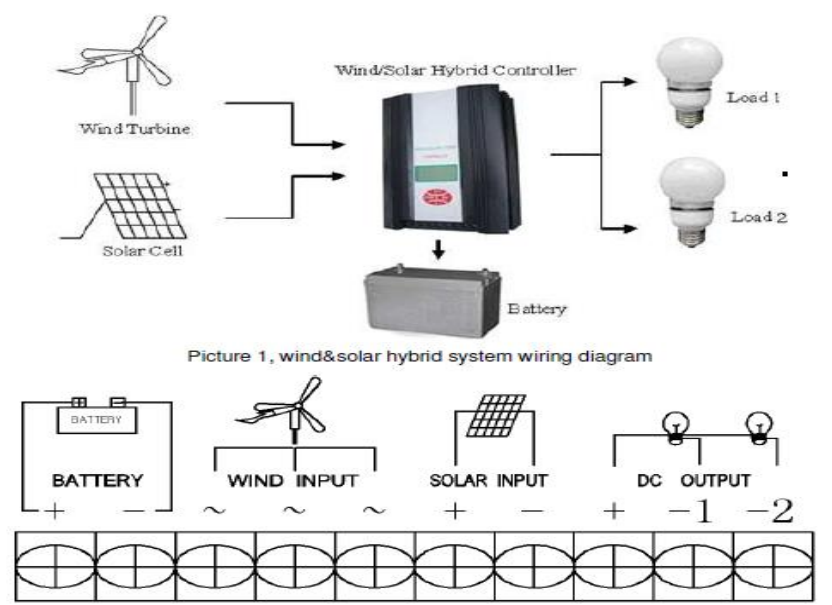

Fig. 6 The connection schema of the installed hybrid power generation system's charge control unit
The battery group is charged with the energy sent from the hybrid charge control unit. For this reason, voltage of the battery group varies depending on the energy amount coming from the system. LCD on the hybrid charge controller indicates current, voltage and power information of the electric energy generated from the wind and solar energy, accumulator and DC outputs. The data can be monitored from the computer display with the Winpowernet interface program via RS-232 and be saved as a Microsoft Excel file whenever it is desired.

Moreover, the operational security of the system is ensured through this controller with the new magnetic brake assembly designed in conformity to the characteristic of the generator.

A simulation block diagram that reflects the explanation of working features, functions and characteristics of the hybrid charge control unit above in the real time was also established. Additionally, a controller was developed to make the energy flow control and coupled inside of the charge control unit. In this way, the hybrid charge controller with a switching method was obtained which is shown in Fig. 7.

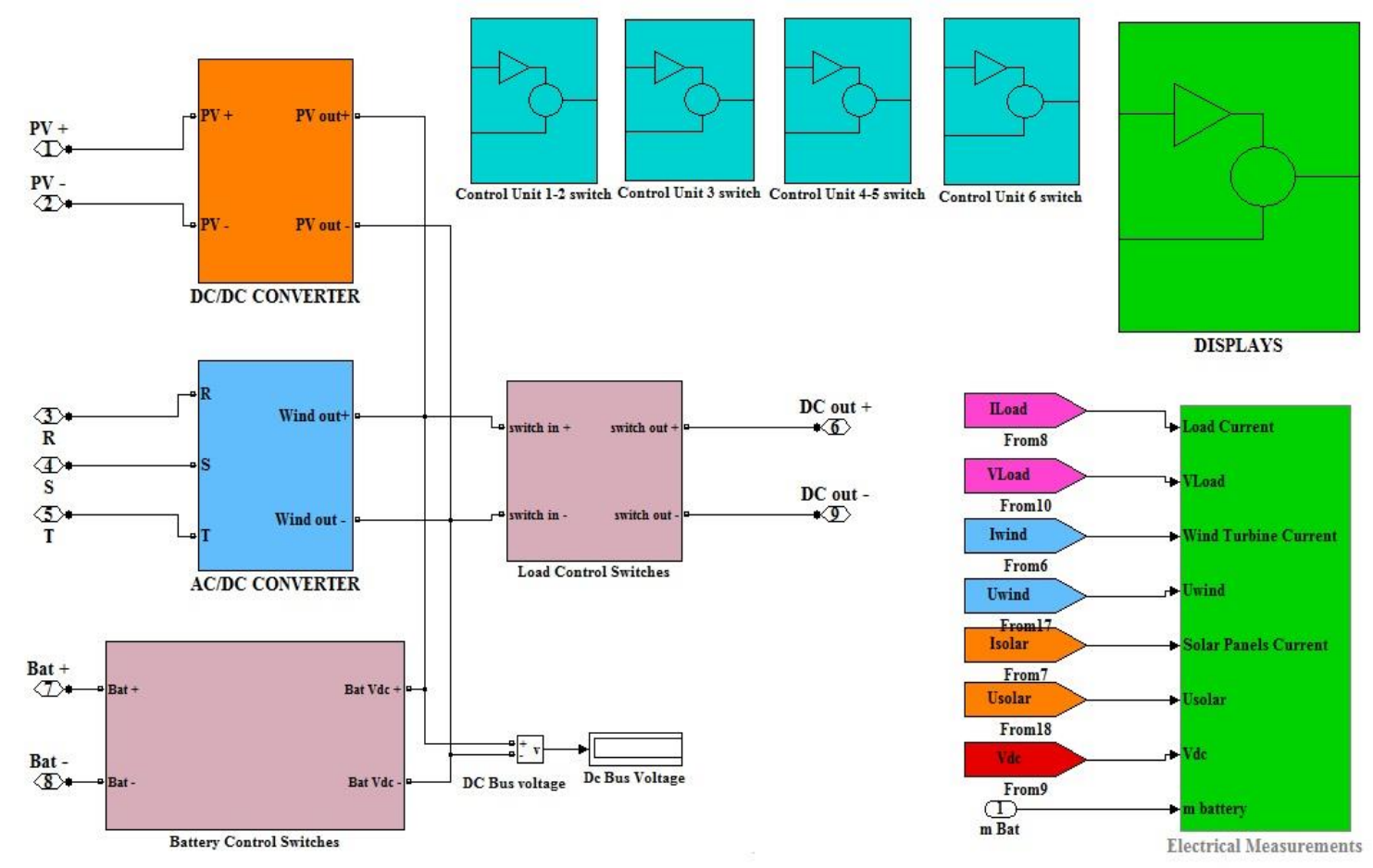

Fig. 7. Simulation block diagram of the hybrid charge controller

\section{Control Strategy For ENERgy MANAGEMENT AND POWER Flow In HYBRID POWER GENERATION SYSTEM}

At this part, the negative conditions in real-time energy flow of the installed and simulated hybrid energy generation system were observed. Upon this, a switched power flow controller was designed to ensure effective use of power from the hybrid power generation system, increase its efficiency, and conserve the system more effectively; and energy flow control of the system was realized.
The working strategy of the switched controller is within the framework of 6 rules as it can be understood from the flow diagram in Fig. 8, and it shows the energy management strategy of the charge control unit in detail depending on the system loading, generation and battery charge conditions. 


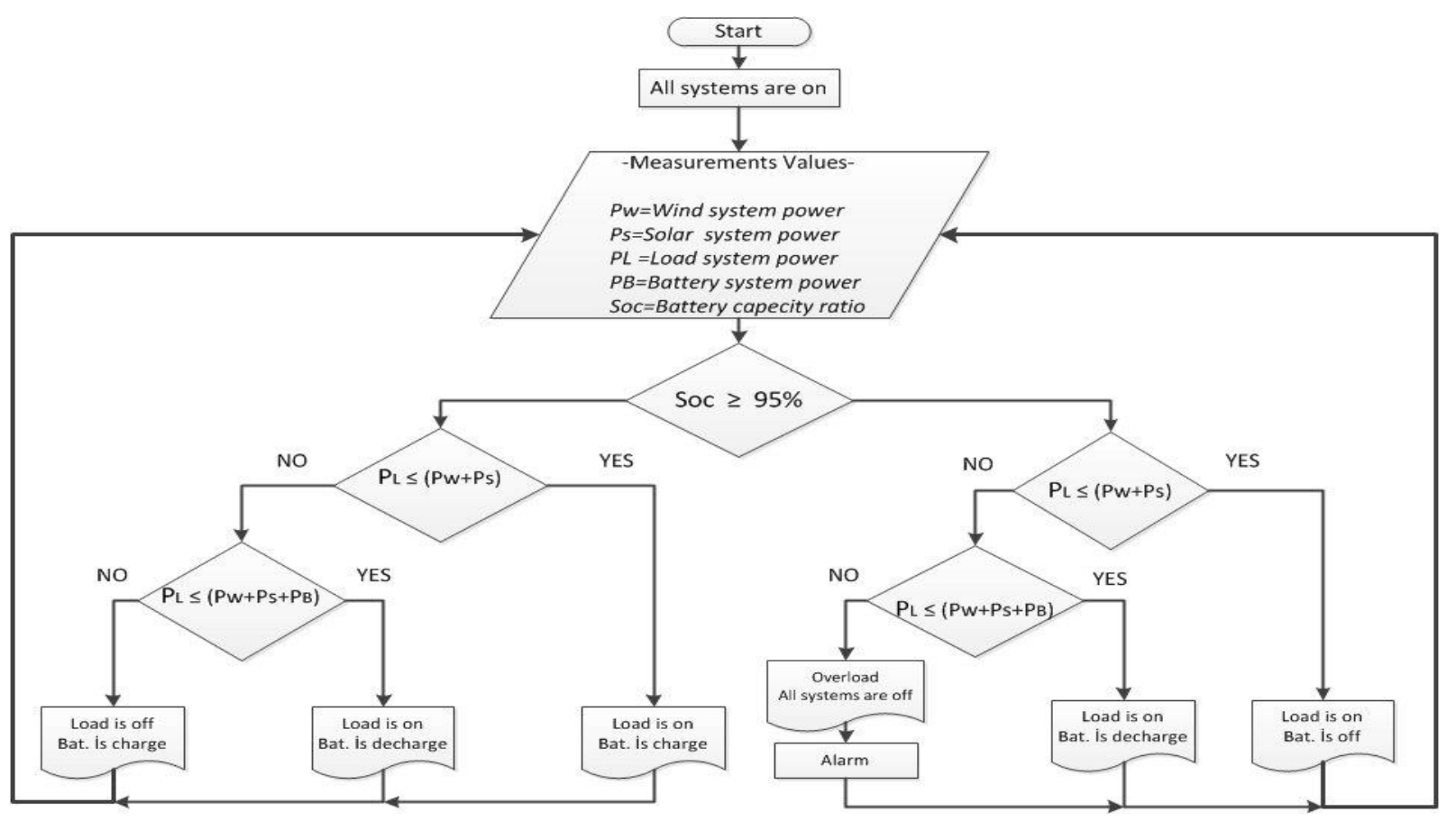

Fig. 8 Flow diagram of energy management strategy

The six rules determined for efficient and effective use of energy are given below in detail.

a) If the battery charge rate is more than $95 \%$ and consumed power is smaller than the total generated power, receiver is powered directly through the windsolar hybrid power generation system after the battery is deactivated.

b) If the battery charge rate is more than $95 \%$, and the consumed power is higher than the total generated power but smaller than the total power generated with battery, receiver is powered with battery power after all the system is activated.

c) If the battery charge rate is more than $95 \%$, and consumed power is higher than the total generated power and power stored in the battery, this means that excessive load is connected. All the systems must be deactivated.

d) If the battery charge rate is less than $95 \%$, and consumed power is smaller than the total generated power, the receiver is powered by being activated and surplus power is stored in the battery.

e) If the battery charge rate is less than $95 \%$, and consumed power is higher than the total generated power but smaller than the total power generated with battery power, the battery must be passed to discharge position by activating the receiver.

f) If the battery charge rate is less than $95 \%$, and consumed power is higher than the total generated power and the total power stored in the battery, this means that excessive load is connected. The load must be deactivated, and it must be charged by activating the battery as it is not full charged.

The main reasons why such a control strategy for the hybrid power generation system has been developed are to increase the efficiency of system by making energy flow control, prevent shortening of battery life and protect the system and receiver against the excessive loading conditions. As a matter of fact, the power generally generated in small power hybrid power generation systems is directly sent to the battery group, and receivers are powered on battery group. However, this condition increases the risk for the battery to be excessively charged or discharged, and it also decreases its lifetime. Unfortunately, energy generated in the installed real-time system is directly sent to the storing units and receivers are powered on them. The cost of batteries constitutes an important part of the system cost. Additionally, when an excessive load is connected to the system, the system elements may be damaged because of the excessive discharge and excessive current drawn from the battery group. In an ideal system, the power needed by the receiver must be directly sent to the receiver to power it up, and if there is surplus generated power, it must be stored in the battery depending on its charge condition.

A switched power flow controller design was made in a manner eliminating the negative conditions expressed above. A simulation study was realized by applying the switched power flow controller to the battery powered hybrid power generation system. 


\section{The Simulation Results AND Discussion}

Energy production does not prove that the system is efficient because the transferring of energy generated in installed systems to the receiver in a controlled manner, the storing of energy in absence of a receiver, and the most importantly, making of power flow controls are also very important for efficiency and productivity of the system. For this reason, recently, a quite many studies have been made for the energy control and these works have still been going on. In general, sending of generated energy directly to the storing units and powering up receivers from there has been emphasized. However, that the storing units are continuously in active position results in decreasing in their lifetime. It should not be forgotten that costs of storing units are very important for the system. In other words, the uncontrolled use of energy decreases the lifetime of system elements and increases the risk for receivers to remain without energy.

In this paper, the simulation results of generation, and consumption powers of the installed and simulated $1170 \mathrm{~W}$ hybrid power generation system were given separately depending on their various loading conditions, and their analyses were made.

TABLE III. SYSTEM LOADING PARAMETERS

\begin{tabular}{|c|c|c|c|c|c|c|}
\hline \multirow[b]{2}{*}{$\begin{array}{l}\text { System } \\
\text { Loading }\end{array}$} & \multicolumn{2}{|c|}{$\begin{array}{l}\text { Wind Power } \\
\text { System }\end{array}$} & \multicolumn{2}{|c|}{ Solar Power system } & \multirow{2}{*}{$\begin{array}{l}\begin{array}{l}\text { Battery } \\
\text { Group }\end{array} \\
\text { SOC } \\
(\%)\end{array}$} & \multirow{2}{*}{$\begin{array}{l}\text { Load } \\
\text { Power } \\
\text { (W) }\end{array}$} \\
\hline & $\begin{array}{l}\text { Wind } \\
\text { Speed } \\
(\mathrm{m} / \mathrm{s})\end{array}$ & $\begin{array}{l}\text { Pitch } \\
\text { Angel } \\
\text { (deg) }\end{array}$ & $\begin{array}{l}\text { Current } \\
\text { (A) }\end{array}$ & Insolation & & \\
\hline $\begin{array}{l}\text { 1.Loading } \\
\text { situation }\end{array}$ & 12 & 0 & 5.12 & 1000 & 95 & 480 \\
\hline $\begin{array}{l}\text { 2.Loading } \\
\text { situation }\end{array}$ & 12 & 0 & 5.12 & 1000 & 95 & 950 \\
\hline $\begin{array}{l}\text { 3.Loading } \\
\text { situation }\end{array}$ & 12 & 0 & 5.12 & 1000 & 95 & 1550 \\
\hline $\begin{array}{l}\text { 4.Loading } \\
\text { situation }\end{array}$ & 9 & 0 & 5.12 & 950 & 95 & 1550 \\
\hline
\end{tabular}

The dynamic behavior of electrical magnitudes (current, voltage and power) was observed by connecting the receivers in different powers to the system. As it can be understood from Table 3, in the first three loading conditions, maximum input values were applied to the wind-solar hybrid power generation system by assuming that the battery group was full charged during full power generation (1170W). In the fourth loading condition, wind input values of the wind power generation system and radiation input values of the solar power generation system were reduced and connected to the receiver power system in the third loading condition. Generation reaction of the hybrid power generation system and reaction of the system against the receiver were observed.
As it can be understood from the simulation curves given below;

In the first loading condition, a $480 \mathrm{~W}$ receiver is connected to the system. In that loading condition, as the consumed power is smaller than the total generated power and the battery group is in full charged condition, the hybrid charge controller deactivates the battery group. Because the hybrid power generation system can feed the consumer without battery support. The power required by the consumer can be met with a generation system that has lower power. The simulation results are shown in Fig. 9.

In the second loading condition, a receiver in power of $950 \mathrm{~W}$ is connected to the system. In this loading condition, as the consumed power is smaller than the total generated power, and the battery group is in full charged condition, the hybrid charge controller deactivates the battery group. However, the power consumed in that loading condition is bigger than the individual generation power capacities of the generation units (wind-solar). For this reason, the power requirement of the consumer must be met through operation of the wind-solar power generation unit together. The simulation results are given in Fig. 10. Principally, 570W of the power consumed by the consumer is provided from the solar power generation system and $380 \mathrm{~W}$ from the wind power generation system.

In the third loading condition, the hybrid power generation system is loaded by increasing the consumer power, $1550 \mathrm{~W}$. As the consumed power is higher than the total generated power in that loading condition, generation power of the hybrid power generation system will be insufficient. In that situation, the needed power requirement must be supported by battery group. According to the simulation results in Fig. 11, the battery group is activated by the hybrid charge controller. In this manner, the consumer is fed from the hybrid power generation with battery support. $600 \mathrm{~W}$ of the power consumed by the consumer is met from the wind power generation system and 570W from the solar power generation system; $1170 \mathrm{~W}$ is provided from the hybrid power generation system and $380 \mathrm{~W}$ from the battery group.

In the fourth loading condition, the wind speed of the system is decreased to $9 \mathrm{~m} / \mathrm{s}$, and solar radiation level is decreased to 950 . Then reaction of the system is observed. Power generation of the hybrid system decreases due to diminishing wind speed and solar radiation. In that case, the total generated power will decrease below $1170 \mathrm{~W}$. To meet the power needed by the consumer, the battery group must give more power than the third loading condition. As it can be seen from the simulation results given in Fig. 12, the power consumed by the consumer is provided by $414 \mathrm{~W}$ wind power generation system, $495 \mathrm{~W}$ the solar power generation system and $640 \mathrm{~W}$ the battery group. 

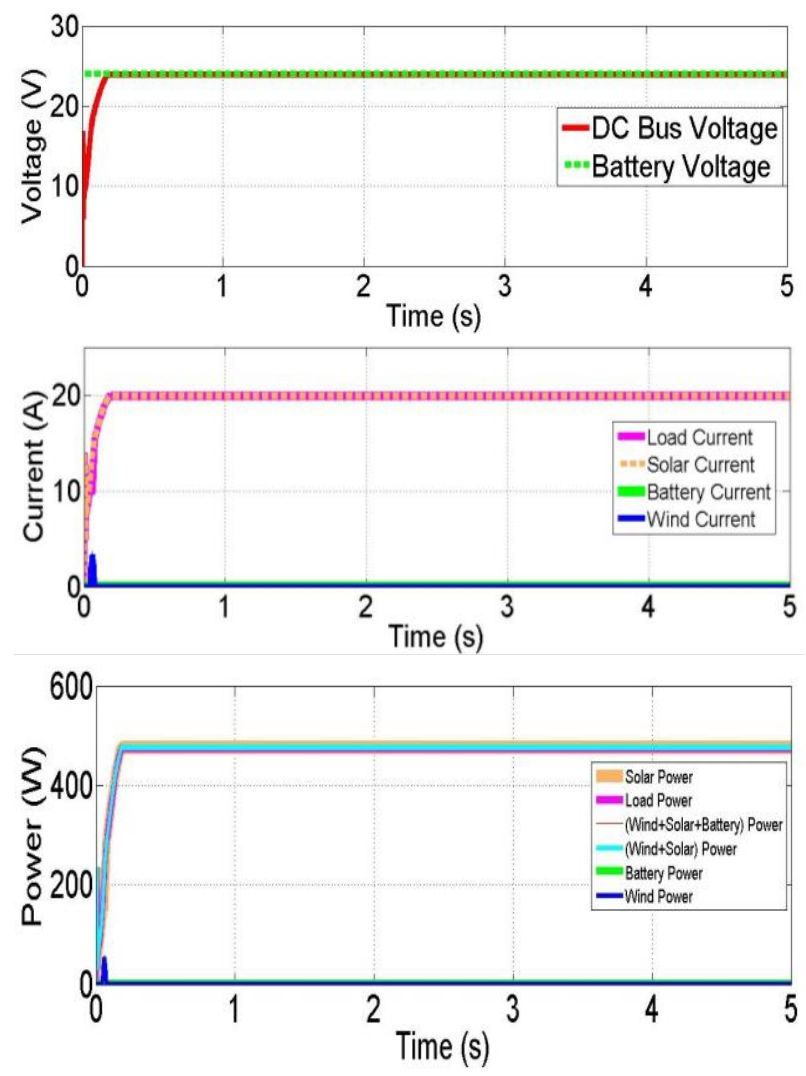

Fig. 9 First loading situation
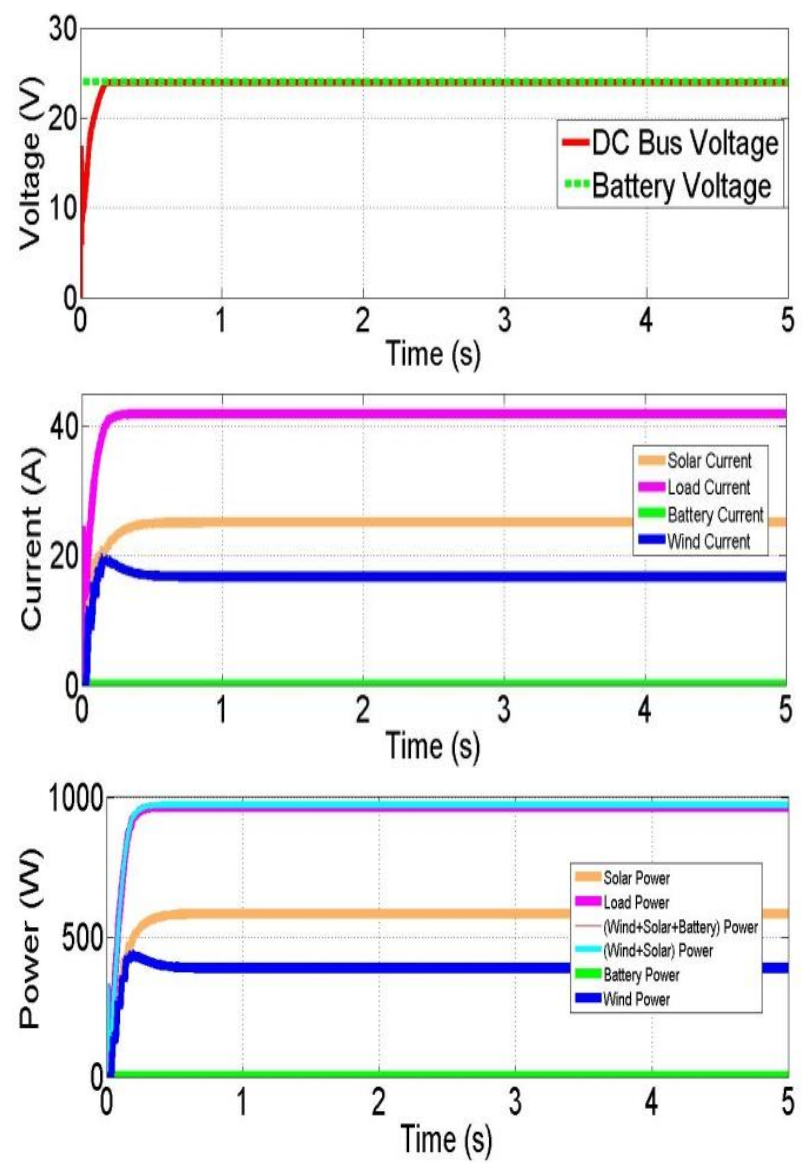

Fig. 10 Second loading situation
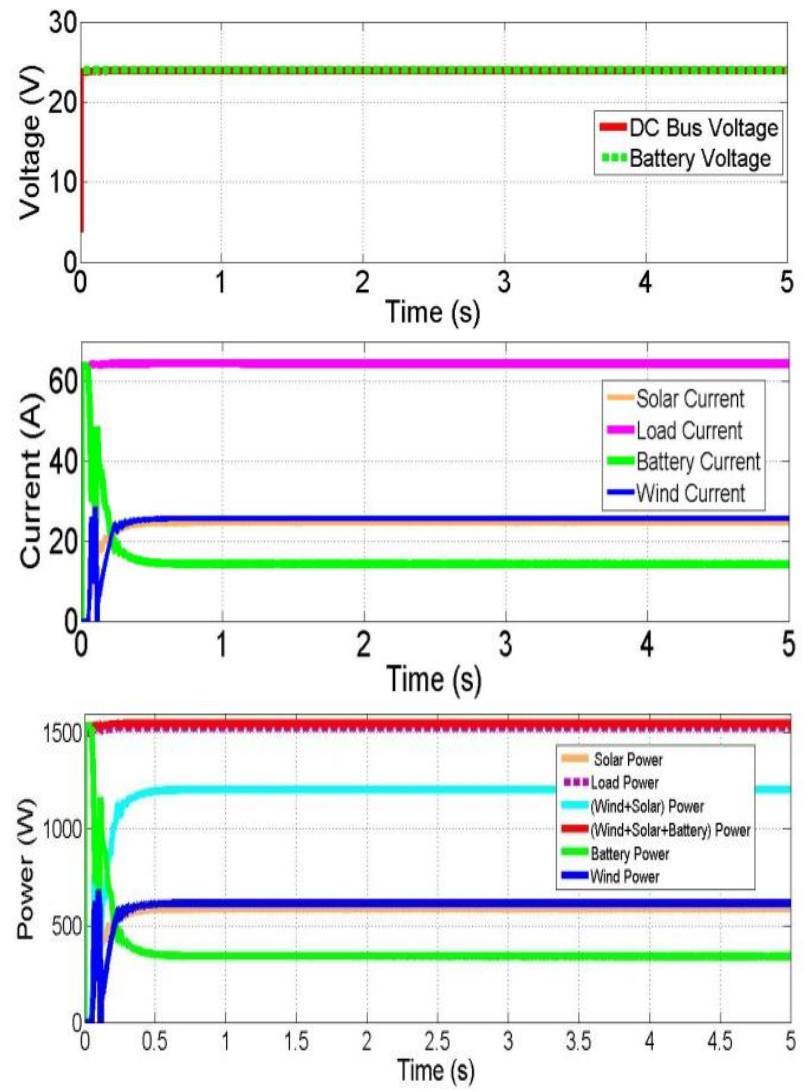

Fig. 11 Third loading situation
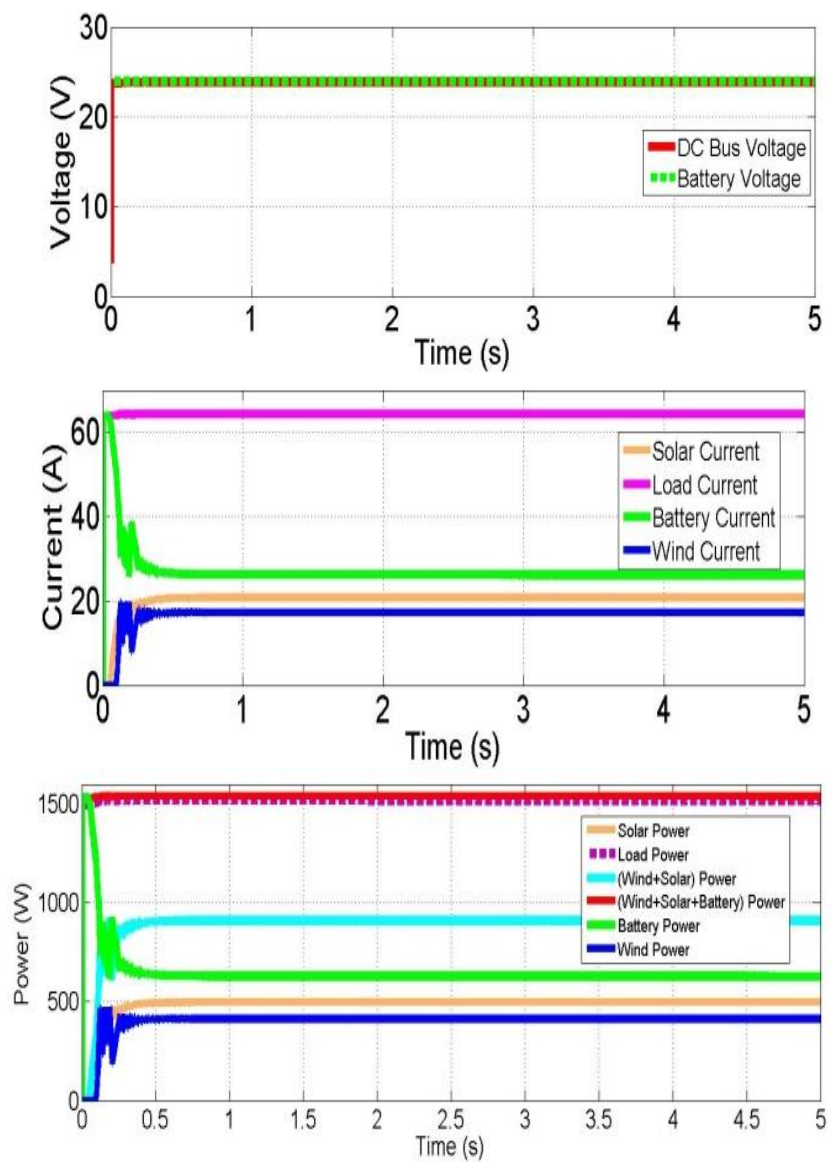

Fig. 12 Fourth loading situation 


\section{CONCLUSIONS}

The application of studies made for energy control directly on real systems may cause occurrence of various unfavorable conditions. Mainly, conditions that give damage to the system elements and the most importantly to the human life have occurred. For this reason, making of exact simulation model of the system to be controlled and then applying control on the simulation primarily will conserve the system elements and human life first and foremost.

In this study, by considering such negative conditions, a real-time modeling of the installed wind-solar hybrid power generation system and energy flow controller to eliminate the troubles in systems were designed. When dealt with the curves obtained from the simulation results, it is seen that there are not big differences in the electrical and mechanical magnitudes in parallel to dynamic behavior of the installed hybrid power generation system. Besides, by exactly comparing the data obtained from the real system with the data obtained from the simulation study, it has been reached the conclusion that accuracy rating of the simulation study realized related to the hybrid power generation system is correct. As a matter of fact, it is seen from the simulation results that the controller designed for energy flow control operates with a very good performance. According to the simulation results, troubles that might occur in energy flow have been eliminated with the switched controller developed. The battery group is activated and deactivated according to behaviors of the system in loading condition. In this manner, decrease in lifetime of the battery is prevented. This decreases the maintenance cost of the system. Moreover, the system is protected against the excessive loading conditions.

On the other hand, students learn to understand how a hybrid power generation system works, the characters of renewable energy sources such as wind energy and solar energy, and how to utilize renewable energy sources efficiently in this study. Moreover, the simulation and experimental environments used to develop and verify the developed hybrid system can be a very effective tool to increase students' knowledge and interests about those subjects.

In the future, thanks to the installed hybrid power generation system, students at electric department will be able to carry out studies on the simulation model instead of studying on the real-time system by taking risk on subjects such as electric generation with renewable energy systems, system control and efficiency of generated energy and soon. In this way, they will develop the new energy control methods and test the controllers they develop on the simulation without any risk so that, will be able to make their applications safely on a real system.

\section{ACKNOWLEDGMENT}

The research for this article has been supported by grant number 10-TEF-05 from Afyon Kocatepe University Scientific Research Projects Coordination Unit.

\section{REFERENCES}

[1] Chedid, R. \& Rahman, S.(1997). Unit sizing and control of hybrid windsolar power systems, IEEE Transactions on Energy Conversion, 12(1), pp. 79-85.

[2] Bonanno, F., Consoli, A., Raciti, A., Morgana, B. \& Nocera, U.(1999). Transient analysis of integrated diesel/wind/photovoltaic generation systems, IEEE Transactions on Energy Conversion, 14(2), pp. 232-238.

[3] Habib, M. A., Said, S. A. M., El Hadidy, M. A. \& Al-Zaharna, I.(1999).Optimization procedure of a hybrid photovoltaic wind energy system, Energy, 24(11), pp. 919-929.

[4] Bayer, H. G. \& Christian, L.(1996).A method for the identification of configurations of PV / wind hybrid systems for the reliable supply of small loads, Solar Energy, 57(5), pp. 381-391.

[5] Morgan , T. R., Marshall, R. H. \& Brinkworth, B. J.(1997).A refined Simulation program for the sizing and optimization of autonomous hybrid energy systems, Solar Energy, 59, pp. 205-215.

[6] Rajendra, P. A. \& Natarajan, E. (2006).Optimization of integrated photovoltaic-wind power generation systems with battery storage, Energy, 31(12), pp. 1943-1954.

[7] Altaş, İ. H. (1993).Control strategies for maximum power tracking and energy utilization of a stand-alone photovoltaic energy system, PhD diss., The University of New Brunswick, Faculty of Engineering, Department of Electrical Engineering, Fredericton, Canada.

[8] Diaf, S., Diaf, D., Belhamel, M., Haddadi, M. \& Louche, A.(2007).A methodology for optimal sizing of autonomous hybrid PV/wind system, International Journal of Energy Policy, 35(11), pp. 5708-5718.

[9] Mittal, R., Sandu, K. S. \& Jain, D. K.(2010).Battery energy storage system for variable speed driven pmsg for wind energy conversion system, Power Electronics, Drives and Energy Systems, 1, pp. 300-304.

[10] El Ali, A., Moubayed, N. \& Outbib, R. (2007). Comparison between solar and wind energy in Lebanon, 9th International Conference on Electrical Power Quality and utilization, pp. 1-5.

[11] Gagliano, S., Neri, D., Pitrone, N., Savalli, N. \& Tina, G. (2009). Lowcost solar radiation sensing transducer for photovoltaic systems, WSEAS Transactions on Environment and Development, 5(2), pp. 119-125.

[12] Barsali, S. \& Ceraolo, M. (2002). Dynamical Models of Lead-Acid Batteries: Implementation Issues, IEEE Transactions on Energy Conversion, 17(1), pp. 16-23.

[13] Moubayed, N., Kouta, J., El-Ali, A., Dernayka, H. \& Outbib, R. (2008). Parameter identification of the lead-acid battery model, 33rd IEEE Photovoltaic Specialists Conference, pp. 1-6.

[14] Onar, O. C., Uzunoglu , M. \& Alam, M. S. (2006). Dynamic modeling, design and simulation of a wind/fuel cell/ultra-capacitor-based hybrid power generation system, Journal of Power Sources, 161(1), pp. 707722 .

[15] Thiringer, T. \& Linders, J. (1993).Control by variable rotor speed of a fixed-pitch wind turbine operating in a wide speed range, IEEE Transactions on Energy Conversion, 8(3), pp. 520-526.

[16] Molina, M. G. \& Juanicó, L. E. (2010). Dynamic modelling and control design of advanced photovoltaic solar system for distributed generation applications, Journal of Electrical Engineering: Theory and Application, 1(3), pp. 141-150.

[17] Valenciaga, F., Puleston, P. F. \& Battaiotto, P. E. (2003). Power control of a solar/wind generation system without wind measurement: a passivity/sliding mode approach, IEEE Transactions on Energy Conversion, 18(4), pp. 501-507.

[18] Borowy, B. S. \& Salameh, Z. M. (1994). Optimum photovoltaic array size for a hybrid wind/PV system, IEEE Transactions on Energy Conversion, 9(3), pp. $482-488$.

[19] Bogdan, S. B. \& Salameh, Z. M. (1996). Methodology for optimally sizing the combination of a battery bank and PV array in a wind/PV hybrid system, IEEE Transactions on Energy Conversion, 11(2), pp. 367-375.

[20] Elhadidy, M. A. \& Shaahid, S. M. (2005). Decentralized /standalone hybrid Wind-Diesel power systems to meet residential loads of hot coastal regions, Energy Conversion and Management, 46(15-16), pp. 2501-2513.

[21] Hajizadeh, A., Tesfahunegn, S. G. \& Undeland, T. M. (2011). Intelligent control of hybrid photovoltaic/fuel cell/energy storage power generation system, Journal of Renewable and Sustainable Energy, 3(4), 043112 . 
[22] Garrison, J. B. \& Webber, M. E. (2011). An integrated energy storage scheme for a dispatchable solar and wind powered energy system, Journal of Renewable and Sustainable Energy, 043101.

[23] Bakić, V., Pezo, M., Stevanović, Ž., Živković, M. \& Grubor, B. (2012). Dynamical simulation of PV/wind hybrid energy conversion system, The 24th International Conference on Efficiency, Cost, Optimization, Simulation and Environmental Impact of Energy, 45(1), pp. 324-328.

[24] Belfkira, R., Zhang, L. \& Barakat, G. (2011). Optimal sizing study of hybrid wind/PV/diesel power generation unit, Solar Energy, 85(1), pp. 100-110.

[25] González, I., Ramiro, A., Calderón, M., Calderón, A. J. \& González, J. F. (2012). Estimation of the state-of-charge of gel lead-acid batteries and application to the control of a stand-alone wind-solar test-bed with hydrogen support", International Journal of Hydrogen Energy, 37 (15), pp. 11090-11103.

\section{BIOGRAPHIES}

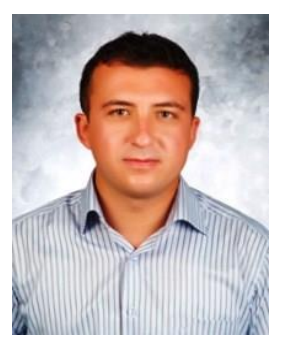

Emrah OGUZ was born in Çanakkale, Turkey, in 1986. He received BSc degree from the Afyon Kocatepe University Technical Education Faculty, Department of Electrical Education, Afyonkarahisar and the MSc degree in Electrical Education from the Afyon Kocatepe University, Institute of Science. He has been studying for $\mathrm{PhD}$ degree in Electric and Electronic Engineering Department at Pamukkale University. He has been a lecturer Electric \& Energy Department at Çanakkale Onsekiz Mart University. He has worked mainly in renewable energy, automatic control applications, power generation systems and control.

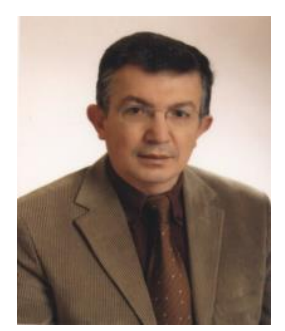

Hasan ÇIMEN received Bachelor and Master Degree in Electrical Education at the Marmara University, Istanbul in 1985 and 1988, respectively. In 1998, he received PhD degree in Power System Control from Sussex University, Brighton, UK. He is currently a Professor and Chairman of ElectricalElectronics Engineering at the University of Afyon Kocatepe in Turkey. His research and educational interests are power system control, intelligent electronic circuits, vocational and technical education, dispersive power generation systems that employ solar arrays, fuel cells, etc.

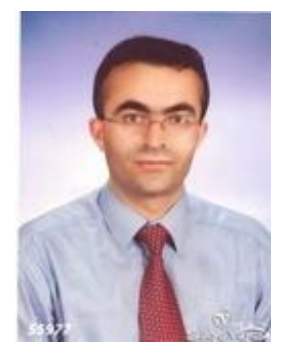

Yüksel OĞUZ was born in Afyon, Turkey, in 1971. $\mathrm{He}$ received $\mathrm{BSc}$ degrees from the Marmara University Technical Education Faculty, Department of Electrical Education, Istanbul, and the MSc and the $\mathrm{PhD}$ degrees in Electrical Education from the Marmara University, Institute for Graduate Studies in Pure and Applied Sciences, in 2000 and 2007, respectively. He has been an assistant professor in the Electronic and Electronic Engineering Department at Afyon Kocatepe University. He has worked mainly in control education, automatic control applications, electrical machines, power generation systems and control, renewable energy, and intelligent control. 